\title{
ВНУТРИШКОЛЬНОЕ ПОВЫШЕНИЕ КВАЛИФИКАЦИИ: РАЗВИВАЮЩИЕ ВОЗМОЖНОСТИ ДЛЯ ПЕДАГОГА
}

\section{INTRA-SCHOOL ADVANCED TRAINING: DEVELOPING OPPORTUNITIES FOR THE DEVELOPMENT}

O. Frolova

L. Ivanova

Summary: The possibilities of the traditional system of advanced training of teachers are analyzed in the article; The problems, specifics and advantages of intra-school advanced training are disclosed; the relevance of continuous self-improvement of the teacher is noted; perspective directions of optimization of the process of advanced training of teachers on the basis of the school have been defined.

Keywords: advanced training of the teacher, types of advanced training, intra-school system of advanced training.
Фролова Олеся Сергеевна

К.п.н., учитель иностранного языка, СОШ № 54 г. Воронеж Olesya.frolova.1984@inbox.ru

Иванова Людмила Викторовна

учитель иностранного языка, МКОУ Алейниковская основная общеобразовательная школа Россошанского муниципального района Воронежской области

Аннотация: В статье анализируются возможности традиционной системы повышения квалификации педагогов; раскрываются проблемы, специфика и преимущества внутришкольного повышения квалификации; отмечена актуальность непрерывного самосовершенствования педагога; определены перспективные направления оптимизации процесса повышения квалификации педагогов на базе школы.

Ключевые слова: повышение квалификации педагога, виды повышения квалификации, внутришкольная система повышения квалификации.
$\mathrm{P}$ еализация стратегии модернизации российского образования диктует необходимость в продуктивно действующем педагоге - способном компетентно реагировать на постоянно усложняющиеся условия педагогической деятельности и действительности; обеспечивать успешную организации образовательного процесса в контексте новой парадигмы и инновационных направлений развития образования; обладать прочно сформированными потребностями, установками в постоянном профессиональном и личностном самосовершенствовании.

Согласно федеральным государственным образовательным стандартам (ФГОС), главной целью профессиональной деятельности педагога является «... создание условий для формирования и развития каждого обучающегося как нравственной, компетентной личности средствами образовательной деятельности» $[11$, c. 7], следовательно возможность ее достижения в значительной степени обусловлена способностью педагога к реализации основных профессионально-педагогических функций - диагностической, ориентационно-прогностической, конструктивно-проектировочной, организаторской, информационно-объяснительной, коммуникативно-стимулирующей, аналитико-оценочной, исследовательско-творческой функций (В.А. Сластенин, В.А. Мижериков и др.).

В свою очередь, для этого от педагога потребуется целенаправленное и своевременное обновление и совершенствование имеющихся, но «устаревающих» зна- ний, умений, компетенций; систематическое формирование положительных профессионально-личностных качеств, т.е. самосовершенствование - сознательное «... управление развитием личности, своих качеств и способностей» [8. с. 83].

Работая длительное время в рамках устойчивой консервативной профессионально-образовательной среды в школе, с одной стороны, многие педагоги оказались сегодня не подготовлены «... к активному, самостоятельному от стереотипов и предвзятости подходу в выдвижении и воплощении нестандартных педагогических идей» [7, с. 29], т.е. к реализации инновационной компетенции. С другой стороны, по-прежнему не дооцененными остаются роль и место компетенции самосовершенствования педагога.

Главная ценность современного педагога и педагога будущего, на наш взгляд, состоит «... не только в его делах и поступках, но и в его умении постоянно работать над собой, самосовершенствоваться, все более глубоко познавать свои возможности и максимально использовать их в своей жизни и деятельности» [8, с. 3]. В свою очередь целенаправленное самосовершенствование может стать «... инструментарием открытия своего неисчерпаемого личностного и творческого потенциала, выявления тех сфер жизнедеятельности, где этот потенциал может быть использован в полной мере» [там же].

Поэтому эффективно содействовать такому продуктивному самосовершенствованию педагога призвана 
система повышения квалификации, как «...целостная образовательная организация, построенная на принципах акмеологического и андрагогического подходов с учетом факторов развития и саморазвития, педагога, средствами самообразования, самоорганизации, самокоррекции ...»[6, с. 88].

В связи с этим приоритетная задача усиления кадрового педагогического потенциала и необходимость определения теоретико-методологических основ сопровождения самосовершенствования педагога в условиях внутришкольного повышения квалификации.

Различные актуальные направления подготовки, переподготовки и повышения квалификации педагога активно исследуются в работах очетественных ученых Н. М. Борытко, С.В. Власенко, В.И. Загвязинского, В.В. Краевского, Э.М. Никитина, Л.Н. Панова и др. Проблемы повышения квалификации педагога, вопросы ее организации становятся предметом исследования также и зарубежных ученых - Н.В. Мукана, Б. Джойса, А. Коула, Б. Шоверса и др.

В нашей работе «Формирование инновационной компетенции педагога в процессе внутришкольного повышения квалификации» (2018) на основе анализа существующих точек зрения отечественных и зарубежных ученых представляем и трактуем его как авторское понимание сущности внутришкольного повышения квалификации «... целенаправленную деятельность педагогов по овладению новыми для них педагогическими ценностями, смыслами, знаниями, умениями, инновационными технологиями, обеспечивающими более продуктивное осуществление образовательного процесса на инновационном уровне» [13, с. 40].

Мы считаем, что инновационный уровень характеризует: способность педагога к восприятию, созданию, применению инноваций; готовность к прогнозированию и предвосхищению возможностей и перспектив внедрения инновационных технологий; способность к продуктивному управлению инновационным процессом, применяя методологические и научные знания о сущности инноваций и инновационной деятельности педагога. В свою очередь, это дает возможность и стимулирует у каждого педагога «... возникновение множества новых возможностей для творческого самоутверждения и самовыражения, субъективно-оригинальных способов самоосуществления в учебно-профессиональной деятельности, во взаимодействии с окружающими» [1, с. 6].

Однако, изучение особенностей имеющихся в системе дополнительного профессионально-педагогического образования видов повышения квалификации педагога (неформальное, информальное и формальное; организованное прямое и косвенное; внешкольные и внутришкольные или внутриучрежденческие виды повышения квалификации $[3,4,5])$ позволяет констатировать, что «... вопросы всех видов повышения квалификации педагогов изучены недостаточно: зачастую в них отсутствует четкое определение понятия «повышение квалификации» или оно трактуется по-разному; нарушена логическая взаимосвязь целей, задач, направлений, методов, средств и форм обучения педагогов, как с их потребностями, так и с потребностями конкретной школы; имеет место недостаточно четкий менеджмент процесса повышения квалификации работников образования; институты повышения квалификации и внутришкольное повышение квалификации не всегда выступают партнерами в реализации общепринятой в государстве образовательной политики» [13, с. 42].

Поскольку система повышения квалификации работников образования как понятие все еще недостаточно изучено, мы обратились к поиску и выявлению ее новых смысло-содержательных характеристик, ее развивающих возможностей и ограничений. Проведен был всесторонний анализ актуальных диссертационных работ (М.Н. Докучаева, В.В. Журавлева, И.К. Кобзенко, Е.В. Ракульцева, Л.Н. Панова, Л.Р. Шафигулина и др), который показал, что «...необходимость утверждения внутришкольного повышения квалификации в качестве важного направления системы повышения квалификации педагогов, подтверждается его возможностями: учитывать особенности, удовлетворять инновационные и образовательные потребности контингента педагогов и учащихся; создавать оптимальные условия, поддерживать и развивать новые традиции школы; учитывать и повышать уровень профессионально-педагогической компетентности отдельных членов педагогического коллектива; обеспечивать систематичность и последовательность в организации процесса повышении квалификации» [13, с. 54].

Также обобщение собственного опыта педагогической деятельности позволяет нам утверждать, что удовлетворение профессионально-образовательных потребностей современного педагога может быть успешно организовано именно в условиях внутришкольного повышения квалификации. Опрос, анкетирование, беседы с педагогами показали, что большинство из них рассматривают внутришкольное повышение квалификации не только как процесс, ориентированный на овладение новыми знаниями, умениями, навыками, на развитие профессиональной компетентности, но и как процесс, содействующий продуктивному самовыражению и самоосуществлению в избранной профессии.

Подтверждение продуктивности процесса внутришкольного повышения квалификации педагога, мы обнаруживаем во многих педагогических исследованиях, где ученые логично и аргументированно раскрывают особенности, оптимизирующие данный процесс: его 
методическое обеспечение; содержательное, технологическое сопровождение процесса обучения педагога, организация мониторинга обучения.

Согласно, Н.М. Борытко не курсовое повышение квалификации, в силу эпизодичности и оторванности от непосредственной работы, а внутришкольная методическая учеба педагогов, может в значительной мере удовлетворить потребности профессионального саморазвития педагога [4].

В частности Э.М. Никитину, исследовавшему теорию и практику многих зарубежных стран по организации и содержанию повышения квалификации педагога, к общим тенденциям развития просвещения сегодня необходимо отнести повышение квалификации преподавателей на базе школы [9].

Мы разделяем точку зрения Л.Н. Пановой, которая считает, что именно школа может и должна сегодня выступать ведущим учебно-методическим центром непрерывного, инновационного профессионального образования педагогов. Становление внутришкольной системы повышения квалификации и ее развитие как приоритетного направления в обучении педагогических кадров, не исключает их подготовку через областной институт повышения квалификации, методические городские центры, тем самым органично дополняя их [10].

В качестве приоритетной задачи внутришкольного повышения квалификации педагога следует рассматривать продуктивное решение проблем организационного, методического, дидактического, содержательно-технологического, психологического обеспечения данного процесса на инновационном уровне.

Педагог в этом процессе призван занимать позицию активного субъекта самовоздействия с целью самоусовершенствования, самопреобразования: стремиться к творческому утверждению в «... деятельности своих индивидуальных способностей, в практическом раскрытии своего потенциала ...» [2, с. 62].

Речь идет о саморазвивающемся педагоге, которому присущи «... целесообразная внутренняя активность и осознанная направленность на разворачивание, совершенствование и формирование свойств, сторон, качеств и т.п. ...» [14, с. 101], которых ранее не было.

Саморазвитие педагога закономерно приводит к самореализации: «... саморазвитие происходит и осознается личностью как процесс самосовершенствования, а его результатом является самореализация человека не только как профессионала, но и как индивидуальности во всей ее многогранности» [цит. по 14, с. 104]. Самореализацию мы рассматриваем как воплощение педагогом собственного духовно-нравственного, интеллектуального, творческого, коммуникативного, эмоционального, энергетического и др. потенциалов в профессии и жизнедеятельности в целом.

Педагог посредством собственных усилий, содеятельности, сотворчества с коллегами осуществляет возможности развития, обогащения Я-профессионального. Способствовать этому будут бесспорные психологопедагогических достоинства внутришкольного повышения квалификации: «... создание психологически комфортной поддерживающей обстановки обучения; обучение в единых профессионально-ценностных ориентирах педагогов школы; возможность учета профессиональных и индивидуальных особенностей личности и деятельности каждого педагога; возможность организации индивидуальной работы с отдельными педагогами; непрерывный мониторинг динамики профессионально-личностных достижений каждого педагога; преемственность, последовательность и непрерывность повышения квалификации всех педагогов; создание и использование возможностей инновационной профессионально-образовательной среды школы» [13, с. 58].

Это позволяет удовлетворять потребности образовательных учреждений в педагогах, ориентированных не только на глубокое усвоение предметной, специальной компетенции, но и владеющих знаниями, стратегиями, способами, приемами непрерывного самосовершенствования и профессионально-личностного развития. А также позволяет решить проблему более продуктивной реализации значительного развивающего потенциала компетентностного подхода в системе внутришкольного повышения квалификации педагога, включая ее формальные, информальные виды.

Ученые активно расширяют границы возможностей внутришкольного повышения квалификации и «... делают акцент на ее важных преимуществах: на возможности гибкого реагирования на меняющуюся ситуацию в образовании; на целенаправленное, предметно-содержательное решение первостепенных задач школы и затруднений конкретных педагогов; возможности осуществления не только предметной подготовки, но и межпредметной и внепредметной; возможности организации командной работы педагогов школы» [13, с. 58].

Очень важно отметить, что внутришкольное повышение квалификации, согласно ученым и практикам, обладает мощным операционально-деятельностным потенциалом реализации не только традиционных, но и инновационных форм (тематические педсоветы, научно-практические семинары, научные педагогические конференции, установленные методические дни, современные информационно-коммуникационные и инновационные технологии, тренинговые, игровые технологии 
обучения и др.) и методов (проблемный, контекстный, проектный, кейс-метод, самоанализ, консультирование, презентация и др.) профессионально-личностного развития педагогов.

K перспективным направлениям усовершенствования системы повышения квалификации педагога на базе школы мы относим: построение ее научно- обоснованной концепции; системную организацию взаимодействия и сотрудничества внешкольной и внутришкольной форм повышения квалификации; реализацию научно-практических основ компетентностного подхода; государственную и административную поддержку профессионально-личностного развития педагога в системе внутришкольного повышения квалификации.

\section{ЛИТЕРАТУРА}

1. Абдалина Л.В. Некоторые аспекты исследования инновационной направленности личности / Л.В. Абдалина. Вестник Воронежского государственного технического университета. 2014, Том 10, № 3.2. С. 4-7.

2. Абдалина Л.В. Психологическая компетентность как фактор профилактики профессиональных деформаций руководителя / Л.В. Абдалина. Известия ВГПУ, 2016. № 1 (270). С. 62-64.

3. Ахлеева Н.П. Курсы повышения квалификации как форма методического сопровождения педагога в межаттестационный период / Н.П. Ахлеева // Конференциум АСоУ: сборник научных трудов и материалов научно-практических конференций. - 2016. - № 2. - С. 915-921.

4. Борытко Н.М. Теория и практика становления профессиональной позиции педагога-воспитателя в системе непрерывного образования: дис. ... д-ра пед. наук / Н.М. Борытко. - Волгоград, 2001. - 275 с.

5. Власенко С.В. Инновационные формы обучения в современной системе повышения квалификации педагогов / С.В. Власенко // Научное обеспечение системы повышение квалификации кадров. - 2014. - № 1. - С. 5-12.

6. Гелястанова Э.Х. Профессиональное самосовершенствование педагога высшего образования в системе повышения квалификации. Успехи современной науки и образования. 2017, № 11-12. С. 87-89.

7. Entrepreneurial spirit of a modern university professor: empirical data Abdalina L., Koval N., Vyunova N., Gosteva S., Khutornaya M. Espacios. 2017. T. 38. № 48. C. 29.

8. Маралов В.Г. Основы самопознания и саморазвития: учеб. пособие для студ. сред. учеб. заведений / В.Г. Маралов. - М.: Издательский центр «Академия», 2002. -256 с.

9. Никитин Э.М. Федеральная система повышения квалификации работников образования: учебное пособие / Э.М. Никитин. - Москва: РИПКРО, 1995. - 194 с.

10. Панова Л.Н. Внутришкольная система повышения квалификации учителей как фактор развития мыслительной деятельности учащихся: дис. ... канд. пед. наук / Л.Н. Панова. - Магнитогорск, 1999. - 173 с.

11. Ривкин Е.Ю. Профессиональная деятельность учителя в период перехода на ФГОС основного общего образования. Теория и технологии / Е.Ю. Ривкин. Волгоград: Учитель, 2015. - 183 с.

12. Федеральный государственный образовательный стандарт высшего профессионального образования (ФГОС ВП0). - URL: http://rc.edu.ru/s8_260307.htm (дата обращения: 24.10.2017)

13. Фролова 0.С. Формирование инновационной компетенции педагога в процессе внутришкольного повышения квалификации: дис. ... канд. пед. наук / О.С. Фролова. - Воронеж, 2017. - 216 с.

14. Что такое акмеология. Вопросы и ответы; Учебное пособие / под ред. Л.В. Абдалиной. - Воронеж: ЦНТИ, 2010. - 163 с. 